\title{
Differences in Ability of Mathematical Metacognition and Self Concept of Students Given Learning IMPROVE Assisted by Macromedia Flash 8 with Think Pair Share
}

\author{
Ramadhani Pertiwi Harahap \\ Education of Mathematic, Post Graduate \\ State University of Medan \\ Medan, Indonesia \\ Corresponding ramadhanipertiwihrp@yahoo.com
}

\author{
Kms. M. Amin Fauzi \\ Department of MathematicsScience Faculty \\ State University of Medan \\ Medan, Indonesia
}

\author{
Pargaulan Siagian \\ Department of \\ MathematicsScience \\ Faculty \\ State University of Medan \\ Medan, Indonesia
}

\begin{abstract}
This study aims to determine: the differences in students' metacognition abilities given the Macromedia Flash 8 assisted IMPROVE learning with think pair share and the differences in self concept given by Macromedia Flash 8 assisted IMPROVE learning with think pair share. This research is a quasi-experimental study. The population of this study were students of class XII SMK Negeri 1 Perbaungan T.A 2017/2018. The sample selection is done randomly by randomizing the class. The instrument used consisted of: metacognition ability test, Self Concept Questionnaire and student activity sheet. Data in this study were analyzed using descriptive statistical analysis and inferential analysis. Inferential analysis of data is carried out by analysis of covariance (ANAKOVA). The results showed that there were differences in students' mathematical metacognition abilities who were given the IMPROVE learning assisted by macromedia flash 8 with think pair share. This is based on the results of the covariance analysis for the model obtained Fcount 4.523> Ftable $=4.00$ and with $\operatorname{sig}=\mathbf{0 . 0 3 7}$. In addition there are also differences in self concept of students who were given the IMPROVE learning assisted by Macromedia Flash 8 with Think Pair Share. This is based on the results of the covariance analysis for the model obtained by $F$ 10.421 $>$ Ftable $=4.00$ and with sig $=0.002$.
\end{abstract}

Keywords-The ability of Mathematics Metacognition; IMPROVE models and Think Pair Share models; macromedia flash 8

\section{INTRODUCTION}

Researchers conducted pre-research observations there are still many teachers who embrace the paradigm of transfer of knowledge in learning, namely not demanding students' mental activities. The biggest part of mathematics that students learn in school is not obtained through mathematical exploration, but through notification. The consequences of conventional learning patterns and exercises on drill questions lead to students being less active and less understanding.

Understanding metacognition for the first time was introduced by Flavell from Stanford University around 1975. He used the term metacognition to state that metacognition is a person's knowledge of the processes of cognition, products or anything related to his thinking process, among others, learning about the relationship of the properties of information or data [1]

Matlin [2] said that metacognition is very important in helping a person in managing the environment and selecting strategies to improve cognitive abilities later. Blakey [3] proposes the basic metacognitive strategies are: (1) Connecting new information to former knowledge. (2) Selecting deliberative strategies. (3) Planning, monitoring, and evaluating thinking processes. According to Kurnia and Ridwan [4] indicators of metacognition ability, namely:
a. Identify the task at hand
b. Monitor the progress of his work
c. Evaluate this progress
d. Predict the results obtained

The low level of mathematical metacognition ability and lack of self-concept of students based on data obtained from 
interviews with mathematics teachers in stateVocational High Schoolof 1 Perbaungan, this can be seen from the daily test scores. In addition, students answer about a problem that measures mathematical metacognition skills, with questions that ask students to do calculations, measured by implementing plans that have been made and prove that the steps are chosen correctly in the form of a single data presentation or group data

In addition to metacognition skills, there are psychological aspects that contribute to one's success completing tasks well. One of the students' learning objectives is expected to have an attitude of respecting the usefulness of mathematics in learning problems, as well as tenacity and confidence in problem solving. This suggests that mathematics learning also emphasizes the 'Self Concept' affective aspects such as students.

According to Burn in Karunia and Ridwan [5] states that Self Concept is a form or element of regular arrangement of self-perceptions. Where one of the indicators is the ability to recognize / identify yourself.

Based on the observations at this school on mathematics learning, students are less able to see the shortcomings and strengths they have, whether they can work on these questions, understand the material, lack confidence and love mathematics.

the results of interviews with one of the mathematics teachers at stateVocational High Schoolof 1 Perbaungan on August 29, 2017 said that the teacher dominated the learning process so that students were less active in learning and to gain knowledge students tended to just wait for the teacher's giving. this is because the teacher wants to complete the subject matter in a timely manner.

So it can be understood that the low ability of mathematical metacognition and Self Concept (selfidentification) is caused by one of them because the learning model has not been implemented which involves the participation of students in a small group. Whereas by using a learning model can be used as a choice pattern, meaning that teachers can choose an appropriate and efficient learning model to achieve their educational goals.

Because it is assumed that the existence of a cooperative learning model that is appropriate, effective and efficient towards learning will produce good results as well. cooperative learning models that are thought to be used to develop students' mathematical and self-concept metacognition skills are Think Pair Share (TPS) learning models and IMPROVE learning.

IMPROVE learning model can also be an alternative that can be used, because this model emphasizes the importance of each student being given the opportunity to develop meaning mathematical by involving their own students in metacognitive discourse. The role of the teacher is to be a facilitator. IMPROVE learning model is one model that can facilitate students to have greater opportunities in dominating learning and can stimulate students' self-perceptions in the learning process. According to Miftahul [6] this model has three independent components, namely
1. Metacognitive activity

2. Interaction with peers

3. Systematic activities of feedbackimprovements

In addition to the Macromedia flash 8-assisted IMPROVE learning model, the Think Pair Share type cooperative learning model is one type of cooperative learning that stimulates student activities in pairs and shares knowledge with other students. Think Pair Share (TPS) learning models begin with thinking that the teacher submits a question related to the material and asking students to think then asking students to pair up by discussing their answers which are then shared with all students in the class.

In addition to choosing a learning model it is also necessary to consider mathematics learning media, this can motivate and encourage students to achieve mathematical metacognition skills and students' self concept. But this has not been done at stateVocational High Schoolof 1 Perbaungan, the learning media used so far have not followed the development of the 21 st century and its utilization is still not well implemented due to the lack of teacher understanding of technology. one of them is using Macromedia Flash 8. Macromedia flash 8 is software that can be used to create an animation. According to Utama [7] this program can display information in the form of writing, pictures, animation, so that students can be more interested in taking mathematics lessons. with the help of Macromedia Flash 8 the learning atmosphere with the IMPROVE model is not boring because in this model there are many stages that are carried out, with the help of Macromedia Flash 8 in which there are exercises in the form of interesting games and some animations used so that the IMPROVE learning model can help teachers provide questions and make students understand the material and practice solving problems given by the teacher

Based on the explanation above, the Macromedia Flash 8 IMPROVE learning and think pair share learning were considered to be able to encourage students to actively get involved in their learning experiences. Learning that is applied in the classroom uses learning groups so students are expected to be able to express ideas in an effort to find solutions to the problems they face and are confident in the abilities they have. Through this study group, students will express their opinions based on the results of their thinking to accept the opinions of students who provide input. Because the learning steps of the Think Pair Share cooperative learning model are different from the Macromedia flash 8 assisted IMPROVE learning, the results of mathematical metacognition ability and self concept of students in each learning will be different.

Based on the above, it is considered important for researchers to conduct research entitled "Differences in Mathematical and Self-Concept Metacognition Ability of Students Given Learning by IMPROVE and Think Pair Share Assisted by Macromedia Flash 8 in stateVocational High School of 1 Perbaungan " 


\section{METHOD}

This study aims to determine differences in mathematical metacognition abilities and self-concept students taught with IMPROVE learning assisted by Macromedia Flash 8 and Think Pair Share in class XII of in stateVocational High School of 1 Perbaungan. Therefore, this research is an experimental research with the type of research is quasi experiment. Because the class used has been formed before.

\section{A. Research design}

The design of this study is in the form of a nonequivalent control group design

TABLE 1. Research Design

\begin{tabular}{|c|c|c|c|}
\hline Group & Pretest & Treatment & Postest \\
\hline Experimen 1 & $\mathrm{O}_{1}$ & $\mathrm{X}_{1}$ & $\mathrm{O}_{2}$ \\
\hline Experimen 2 & $\mathrm{O}_{1}$ & $\mathrm{X}_{2}$ & $\mathrm{O}_{2}$ \\
\hline
\end{tabular}

\section{Explanation}

$\mathrm{O}_{1}$ : Experimental group pretest 1 and 2

$\mathrm{O}_{2}$ : Experimental group posttest 1 and 2

$\mathrm{X}_{1}$ :MPROVE learning assisted by Macromedia Flash 8

$\mathrm{X}_{2}$ : Cooperative learning Think Pair Share

\section{B. Research Instruments}

This study uses two types of instruments, namely test and non-test instruments. The test instrument is a mathematical metacognition ability test, while a non-test instrument is a questionnaire to measure students' self concept

\section{Instrument Trial}

Before the research instrument was used, the contents of all test devices were validated and analyzed by three lecturers and two teachers of mathematics. Content validity is determined based on the suitability between the question grid and the item.

After expert validation of the research instruments, then the instruments with adequate content validity were tested on students who were outside the research sample. This is done to see the validity, reliability, distinguishing power and level of difficulty of the item.

\section{Descriptive Statistical Analysis}

\section{A. Descriptive Analysis of Metacognition and Self Concept Abilities}

To determine metacognition ability criteria based on the average and standard deviation. Whereas the determination of the minimum standard of metacognition ability is guided by the Minimum Completeness Criteria (MCC). Based on this view, the results of the students' metacognition ability test can be presented in the following interval criteria [8]

MCC $>$ Mean $+1,75 \mathrm{SD}$

Mean $+1,75 \mathrm{SD}<\mathrm{MCC}<$ Mean $+0,75 \mathrm{SD}$ high

Mean $+0,75 \mathrm{SD}<\mathrm{MCC}<$ Mean $-0,75 \mathrm{SD} \quad$ Medium
Very high
Mean - 0,75SD $<$ MCC $<$ Mean - 1,75SD Low

MCC $<$ Mean $-1,75 \mathrm{SD}$

Very low

\section{E. B. Inferential Statistical Analysis}

Inferential statistical analysis is used to test the first hypothesis in this study with inferential ANACOVA statistics. The data analysis design can be seen in Table 2 below:

TABLE 2. Data Analysis Design for ANAKOVA [9]

\begin{tabular}{|c|c|c|c|c|}
\hline & \multicolumn{2}{|c|}{$\begin{array}{c}\text { Macromedia Flash 8 assisted } \\
\text { IMPROVE Learning Group }\end{array}$} & \multicolumn{2}{c|}{ TPS group } \\
\cline { 2 - 5 } & Postest & Pretest & Postest \\
\hline$X_{11}$ & $Y_{11}$ & $X_{21}$ & $Y_{21}$ \\
\hline$X_{12}$ & $Y_{12}$ & $X_{.22}$ & $Y_{22}$ \\
\hline$\ldots \ldots$ & $\ldots \ldots$ & $\ldots \ldots$ & $\ldots \ldots$ \\
\hline$\ldots \ldots$ & $\ldots \ldots$ & $\ldots \ldots$ & $\ldots \ldots$ \\
\hline$X_{1 n}$ & $Y_{I n}$ & $X_{2 n}$ & $Y_{2 n}$ \\
\hline
\end{tabular}

Description :

$\mathrm{X}_{1}$ : The average score as an accompanying variable in the Macromedia Flash IMPROVE Learning group

Before ANAKOVA was used to analyze the data, it was necessary to test the normality and homogeneity of the data of the TPS learning group and the macromedia flash assisted IMPROVE learning group 8 . Then the regression model between the dependent variable $\mathrm{Y}$ (final ability / posttest) and the accompanying variable $\mathrm{X}$ (initial ability / pretest) fulfilled the linear relationship simple in each category or level of factor to be considered.

\section{RESULTS AND DISCUSSIONS}

\section{A. The Ability Of Mathematics Metacognition}

The metacognition ability test was conducted twice, namely pretest and posttest tests. The pretest and posttest were followed by 64 students so that in the data analysis that became the subject of this study were 64 students who followed the pretest and posttest.

TABLE 3. Data on Metacognition Pretest Results

\begin{tabular}{|l|c|c|c|}
\hline \multicolumn{1}{|c|}{ Aspect } & $\begin{array}{c}\text { Maximum } \\
\text { score }\end{array}$ & $\begin{array}{c}\text { Average } \\
\text { Experiment } \\
\text { Class 1 }\end{array}$ & $\begin{array}{c}\text { Average } \\
\text { Experiment } \\
\text { Class 2 }\end{array}$ \\
\hline $\begin{array}{l}\text { Develop a plan of } \\
\text { completion action }\end{array}$ & 4 & 12,1 & 10,9 \\
\hline $\begin{array}{l}\text { Monitor completion } \\
\text { actions }\end{array}$ & 4 & 6,0 & 5,2 \\
\hline $\begin{array}{l}\text { Evaluate completion } \\
\text { actions }\end{array}$ & 4 & 2,9 & 2,5 \\
\hline
\end{tabular}


TABLE 4.Data on Mathematical Metacognition Postes

\begin{tabular}{|l|c|c|c|}
\hline \multicolumn{1}{|c|}{ Aspect } & $\begin{array}{c}\text { Maximum } \\
\text { score }\end{array}$ & $\begin{array}{c}\text { Average } \\
\text { Experiment } \\
\text { Class 1 }\end{array}$ & $\begin{array}{c}\text { Average } \\
\text { Experiment } \\
\text { Class 2 }\end{array}$ \\
\hline $\begin{array}{l}\text { Develop a plan of } \\
\text { completion action }\end{array}$ & 4 & 15,8 & 15,8 \\
\hline $\begin{array}{l}\text { Monitor completion } \\
\text { actions }\end{array}$ & 4 & 12,2 & 10,6 \\
\hline $\begin{array}{l}\text { Evaluate completion } \\
\text { actions }\end{array}$ & 4 & 8,1 & 5,7 \\
\hline
\end{tabular}

TABLE 5. Covariance Analysis for Complete Design of Mathematical Metacognition Ability

Tests of Between-Subjects Effects

\begin{tabular}{|c|c|c|c|c|c|}
\hline \multicolumn{6}{|c|}{ Dependent Variable: POSTES } \\
\hline Source & $\begin{array}{c}\text { Type III Sum of } \\
\text { Squares }\end{array}$ & df & $\begin{array}{l}\text { Mean } \\
\text { Square }\end{array}$ & $\mathbf{F}$ & Sig. \\
\hline $\begin{array}{l}\text { Corrected } \\
\text { Model }\end{array}$ & $438,221^{\mathrm{a}}$ & 2 & 219,110 & $\begin{array}{r}17,59 \\
8\end{array}$ &, 000 \\
\hline Intercept & 375,690 & 1 & 375,690 & $\begin{array}{r}30,17 \\
3\end{array}$ & ,000 \\
\hline PRETES & 209,455 & 1 & 209,455 & 16,82 &, 000 \\
\hline MODEL & 56,322 & 1 & 56,322 & 4,523 &, 037 \\
\hline Error & 759,514 & 61 & & & \\
\hline Total & 75795,000 & 64 & & & \\
\hline $\begin{array}{c}\text { Corrected } \\
\text { Total }\end{array}$ & 1197,734 & 63 & & & \\
\hline
\end{tabular}

a. R Squared $=, 366($ Adjusted R Squared $=, 345)$

Based on the results of the covariance analysis for the model obtained Fcount 4.523> Ftable $=4.00$ and with sig $=$ 0.037 . Because the sig level is smaller than 0.05 , so $\mathrm{HO}$ is rejected $\mathrm{H} 1$ is accepted, it can be concluded that there are differences in mathematical metacognition abilities between students given IMPROVE learning assisted by macromedia flash 8 and think pair share learning

\section{B. Self Concept Students}

TABLE 6.Think Pair Share Percentage of Results of Self Concept Mathematics Questionnaire with IMPROVE Learning Model Assisted by Macromedia Flash 8 and Think Pair Share Learning

\begin{tabular}{|c|c|c|}
\hline Indicator & $\begin{array}{c}\text { Macromedia } \\
\text { Flash 8 assisted } \\
\text { IMPROVE } \\
\text { Learning Group }\end{array}$ & $\begin{array}{c}\text { TPS } \\
\text { group }\end{array}$ \\
\hline $\begin{array}{c}\text { 1. Having the ability to recognize } \\
\text { / identify yourself }\end{array}$ & 22,25 & 21,71 \\
\hline
\end{tabular}

\begin{tabular}{|l|c|c|}
\hline $\begin{array}{c}\text { 2 Have a view or appreciation of } \\
\text { the ideal self-image in the } \\
\text { future }\end{array}$ & 18,53 & 16,68 \\
\hline $\begin{array}{c}\text { 3. Have an assessment of yourself } \\
\text { in terms of achieving } \\
\text { expectations }\end{array}$ & 18,12 & 15,15 \\
\hline $\begin{array}{l}\text { 4. Have a standard of living that } \\
\text { suits him }\end{array}$ & 32,37 & 25,43 \\
\hline amount & 2921 & 2528 \\
\hline Average & 91,28 & 79 \\
\hline
\end{tabular}

From the data obtained above, it can be concluded that there are differences in self concept of students in the Macromedia Flash 8 IMPROVE learning class and Think Pair Share learning.

TABLE 7. Covariance Analysis for Student Self Concept Scale Complete Design

\begin{tabular}{|c|c|c|c|c|c|}
\hline \multicolumn{6}{|c|}{ Tests of Between-Subjects Effects } \\
\hline \multicolumn{6}{|c|}{ Dependent Variable: S.CONCEPT } \\
\hline Source & $\begin{array}{l}\text { Type III } \\
\text { Sum of } \\
\text { Squares }\end{array}$ & Df & $\begin{array}{c}\text { Mean } \\
\text { Square }\end{array}$ & $\mathrm{F}$ & Sig. \\
\hline $\begin{array}{c}\text { Corrected } \\
\text { Model }\end{array}$ & $3213,320^{\mathrm{a}}$ & 2 & 1606,660 & 19,152 & 000 \\
\hline Intercept & 2814,001 & 1 & 2814,001 & 33,544 & .000 \\
\hline PRETES & 968,930 & 1 & 968,930 & 11,550 & 001 \\
\hline MODEL & 874,190 & 1 & 874,190 & 10,421 &, 002 \\
\hline Error & 5117,289 & 61 & 83,890 & & \\
\hline Total & $\begin{array}{r}469881,00 \\
0\end{array}$ & 64 & & & \\
\hline Corrected Total & 8330,609 & 63 & & & \\
\hline \multicolumn{6}{|c|}{ a. R Squared $=, 386($ Adjusted R Squared $=, 366)$} \\
\hline
\end{tabular}

Based on the results of the covariance analysis for the model obtained Fcount $10.421>$ Ftable $=4.00$ and with sig $=0.002$. Because the sig level is smaller than 0.05 , so $\mathrm{H} 0$ is rejected $\mathrm{H} 1$ is accepted. So it can be concluded that there are differences in mathematical self concept between students who were given IMPROVE learning assisted by macromedia flash 8 and the learning of think pair share.

\section{CONCLUSIONS}

There are differences in students' metacognition skills who learn using the IMPROVE learning model assisted by Macromedia Flash 8 and students who learn how to apply 1 think pair share. In addition there are also differences in self concept of students who learn to apply the IMPROVE learning model assisted by Macromedia Flash 8 with students who learn to apply think pair share

\section{REFERENCES}

[1] Chairani, Zahra. 2016. Metakognisi Siswa dalam Pemecahan Masalah Matematika. Yogyakart: Deepublish

[2] Matlin, M. W. (1998). Cognition. Philadelphia: Harcourt Brace College Publisher

[3] Blakey, E. \& Spence, S. 1990. Developing Metacognition, Clearinghouse on Information Resources Syracusa, New York. 
[4] Lestari, Eka Kurnia dan Muhammad Ridwan Yudhanegara, 2015 "Penelitian Pendidikan Matematika" Bandung "PT Refika Aditama

[5] Lestari, Eka Kurnia dan Muhammad Ridwan Yudhanegara, 2015 "Penelitian Pendidikan Matematika" Bandung " PT Refika Aditama

[6] Huda, Miftahul. 2013. "Model-Model Pengajaran dan Pembelajaran". Yogyakarta: Pustaka Pelajar.
[7] Utama, Noris Putra. "Penggunaan Macromedia Flash 8 Pada Pembelajaran Dimensi Tiga" (Online), Vol. 1 No. 1 (2012) : Jurnal Pendidikan Matematika, Part 2: Hal. 51-59

[8] Jaya, Indra dan Ardat. 2013. "Penerapan Statistika Untuk Pendidikan". Bandung: Citapustaka Media Perintis.

[9] Kadir. (2015). Statistika Terapan.Jakarta: PT Raja Grafindo 